\title{
HUMAN RIGHTS AND THE EIGHTEENTH-CENTURY MIND: OR, CONJECTURAL SAVAGES, FICTIONAL HUMANS AND THE PERFORMANCE OF RIGHTS
}

\author{
By Joel P. Sodano Jr.
}

In 2004, historian Lynn Hunt published an article entitled “The $18^{\text {th }}$ Century Body and the Origins of Human Rights.” Therein she argues that humanist experiences of the body that emerge with the penal reform movement of eighteenth-century Europe represent the origins of the concept of human rights as we know it today.

Hunt's primary concern is the emergence of a "rights possessing body" that causes a major shift in thinking around mid-century. In outlining this shift, she first illustrates how the rise in the popularity of portraiture during the latter half of the eighteenth-century functioned to "encourage the view that each person was an individual, that is, single, separate, distinctive and original" (Hunt 43). Hunt suggests that such a proliferation of "individuated bodies" lays the groundwork for a new kind of emotional experience requisite for modern human rights-a feeling of sympathy for someone else whose own autonomous body has been violated.

Hunt undertakes a thorough investigation of juridical treatises in order to show that "In the 1770s and 1780s, penal reform and human rights language would prove to be mutually reinforcing [throughout] the western world" (Hunt 46). The structures of these tracts follow a pattern similar to the one exemplified in Jacques-Pierre Brissot de Warville’s 1780 “Discourse on the Means of Preventing Crimes in France" wherein he invokes the "sacred rights that man holds from nature” as a foundation for denouncing the various forms of cruelty (whipping, pillorying, water torture, branding, breaking on the wheel, hanging, disemboweling, burning at the stake, drawing and quartering, etc.) that were, up to that point, judicially sanctioned forms of 
corporal punishment (Hunt 44, 50). Hunt suggests that such rhetoric retroactively introduces a concept of the body as inviolable by applying a notion of the rights of man to the individual who suffered at the behest of a "justice" system.

Thus, she concludes that "In a few decades [...l]ong-held notions of [...] punishment and truth through pain had withered under the pressure of new experiences of the body that in turn facilitated the emergence of new conceptions of rights of individuals and Enlightenmentinspired critiques of the old ways. What had [once] been commonplace [now] became barbaric and savage” (Hunt 51). Though she recognizes the Foucauldian implications of her thesis, Hunt declares that normalization through "self control and surveillance," while not ideal, is both preferable to its historical antecedent of spectacular punishment and "necessary in some measure for democratic societies” (my italics, 42). If Hunt’s historical outline is correct, it perhaps accepts the normalizing implications of a "rights-possessing, autonomous, inviolable self” too readily, for her explication fails to account for the fact that eighteenth-century penal reform rhetoric places its measure of "human progress" upon a problematic axis of barbarity and humanity.

It is my contention that, by attempting to specify a space where natural law (i.e. natural rights) and positive law coincide, the socio-juridical thinkers that championed the humanist turn in European jurisprudence also effected a more radical specialization as well. Focusing on the British tradition between 1767 and 1786, this essay will suggest that the rhetoric of penal reform, along with its adoption of an embodied concept of "human rights," simultaneously creates the parameters according to which those (supposedly universal) rights do not apply--the figure of the inhuman savage. As a corrective, this essay will look to Adam Ferguson’s An Essay on the History of Civil Society which complicates traditional stadial models of human history. 
Keeping the barbarity / humanity axis in mind, it is fitting that William Eden, Lord Auckland begins his 1771 Principles of Penal Law with a history "Of the Origin of Legislation." In the opening two paragraphs, he invokes the language of contract theory in order to illustrate how, through civil laws, "the natural herd is refined into a political state" (my emphasis, Auckland 2). He founds his argument of the origin of legislation on the notion that: In the formation of societies[,] mutual utility is the instinctive principle of union. But reason[,] co-operating with instinct[,] carries the association still further, and points out the insufficiency of a system merely gregarious. The unlimited enjoyments of Individuals are found incompatible with the existence of a collective Body; rules of conduct and covenants are introduced; and the moral duties of benevolence, justice, and adherence to compacts, become as evident to human understanding, as they are essential to human happiness. (my emphasis, Auckland 1)

It first bears noting that the "unlimited enjoyments of individuals" would include the unrestrained access to the bodies of other individuals; thus, in Auckland's version of the stadial progression of civil society, a move toward the separate inviolability of individuals is necessary in order for the collective Body to function. On this account, Hunt's point is well-taken: the human rights for which Auckland will later advocate are based on the notion that, as Randal McGowen asserts, “[g]ood governments [respect] the liberties of their subjects and the rights of their bodies" (McGowen 669).

Beyond this, we should not miss the shift in language that occurs in the above quoted paragraph. Beginning with what we should recognize as the markers of a state of nature, Auckland suggests societies operate on "instinct" (that is, upon natural, animal, or brutish 
impulses). Also, one should notice that Auckland's society is not yet peopled with "humans" until moral duties, justice, and adherence to compacts become evidence of human understanding and the essential grounds for human happiness. Therefore, Auckland makes clear that the progress from the infancy of civilization to maturity culminates in "civil liberty [as] the aggregate of those portions of natural liberty, which are given up by the constituent members of society" (my emphasis, 2). And, as the "natural herd" is refined into the collective body of a political state, its borders begin to solidify around the distinction between the human and its savage antecedents.

This point becomes complicated when Auckland tries to reconcile his stadial explanation of human progress with the long preceding notion of a universal natural law upon which all positive law (according to penal reformers) should be based. In calling for a graduated mitigation of punishments in relation to crimes (as opposed to the previous English practice of prescribing death for crimes that run the gamut from pick-pocketing to high treason), Auckland makes an appeal to "the unwritten law of God imprinted on the heart of Man; to that natural sympathy better felt than expressed, which forbids us to give unnecessary Pain to each other” (my emphasis, 5).

The same political "human" from the beginning of Auckland's history, who has moved out of the "natural herd," has now gained a new nature that is distinctly human in God's flock. William Blackstone's Commentaries on the Laws of England (written and revised over subsequent drafts between 1765 and 1769) makes the same move by introducing the concept of "the doctrines [of] divine law [...which], when revealed, are found [...] to be really a part of the original law of nature" (47). The apparent redundancy of divine law and natural law in Blackstone's schema is significant because it reveals that they are precisely not the same. Divine 
law is a notion of natural law that is revealed to individuals in society as they progress out of an instinctual state of nature to form a political state of moral duties, justice, and adherence to compacts; therefore, an equation occurs between the establishment of civil society, the recognition of "divine law," and a becoming human which sets the parameters according to which the concept of "human rights" can apply..

A quote from the 1775 edition of Auckland's Principles, cited in Hunt, should clarify the point I'm making here. Auckland states that “[w]hen the rights of human nature are not respected, those of the citizen are generally disregarded. Those areas are in history found fatal to liberty, in which cruel punishments predominate” (my emphasis, 51). Hunt concludes from this that "A 'civilized' society defended the human rights of its citizens and therefore forbade torture or cruel punishment” (51). Perhaps, but at the very same time, this kind of rhetoric is carving out an exclusive space for the applicability of those rights. The terms "civilized" and "citizen," in turn, become markers for the "savage" exceptions—-those that must necessarily be created without rights in order for the stadial system of the process of civilization to function.

Volume two of Henry Dagge's 1774 Considerations on Criminal Law provides an explicit instance of the division that occurs at the moment penal reform appeals to human rights. This occurs after his discussion of the statutory punishment for high treason, which was "that the offender shall be drawn upon a hurdle to the gallows, and there hung by the neck, and cut down alive; his entrails taken out, and burnt; his head cut off, his body quartered; and his head and quarters to be at the King's disposal” (8). Almost more shocking than the spectacular punishment is the argument that Dagge puts forth to illustrate its "barbarity." After first establishing that such penalty “disgraces humanity,” he declares that "[i]t is such savage butchery as might even stain a Hottentot" (my emphasis, 10). He continues, "It seems difficult to conceive that such a Judgment 
could have been devised by a human being; or having been established in the days of ignorance, bigotry, and barbarity, that it should be suffered to continue at the present civilized and enlightened period” (10).

The repercussions of his use of the word "stain” (which in the eighteenth-century means to blush as commonly as it means to be morally corrupted) are far too numerous to explore thoroughly here, but even if we stay with the latter definition, we see that this act at which “nature shudders” (here we should read the moralizing nature of Blackstone’s revealed law) and by which humanity is disgraced, immediately produces its logical counterpart, the image of the savage. We can deduce from this that the Hottentot, who exists at an earlier point on the stadial timeline of civilization, is not sensitive to the concept of human rights which causes Dagge to be so disgusted. In other words by virtue of their exclusion from the very specific set of moral, social, and judicial circumstances that define a political state indicative of "humanity," the Hottentots are marked as inhuman.

What makes Dagge’s Considerations on Criminal Law worthy of mention amid so many other tracts that share a similar rhetorical structure is that the specificity of the Hottentot reminds us what is at stake in these texts. For it is not merely a matter of a figurative savage vs. civilized image used as a means of rhetorical hyperbole; there were actual groups of people to which the epithet of "savage" was thought to apply.

One Eighteenth- century writer that at least calls into question the strict distinctions that form along the barbarity / humanity or state of nature / human nature axis of human progress is Adam Ferguson, a historian, philosopher, and a figure of the Scottish Enlightenment. Ferguson’s 1767 work entitled A n Essay on the History of Civil Society (which is, in part, as Fania OzSalzberg puts it, “a reiteration of the stadial history of human advance [...] from 'savage’ to 
'barbarian' and on to 'commercial' and 'polite'”) may seem a strange place to mount an interrogation of the penal reform movement's sense of history (xviii-xix).

Ferguson uses similar language to those which I have exhibited above, referencing savages and barbarians in his explorations of the "progress" of "rude nations"; he even mentions specifically the Hottentots as well as Native Americans, Tartars, Laplanders, Indians, etc.. But an important distinction between Ferguson and the others is that he demands we not make assumptions of fixity regarding the "simultaneous existence of disparate societies $[\ldots]$ in various stages of progress and mutual awareness” along a shared teleological track of history (OzSalzberg xx). Instead, he insists that the various environments in which societies are situated "bring human affairs to a state of complication”; such a state of complication should prove problematic for any universal notion of rights, but it is especially detrimental for a concept of the rights of man grounded on the precept that such rights are attained through an advanced progress which has opened up an irrevocable chasm between the state of nature and human nature. Among the questions that this begs (which I do not have time to explore further here) is whether or not Ferguson's state of complication implies a complete moral relativism. What I argue here is that it certainly gives cause to reconsider Ferguson's contemporaries' appeals to universal rights which result in exclusionary ends.

From the very beginning of Ferguson's Essay, he diverges from the above-noted conceptions of stadial history as irrevocable "progress" by calling into question even the possibility of attaining the historical records for the "state of nature," which is commonly conceived of as the original point from which civil societies unfold throughout time. The fact that he does this as a means of establishing another treacherous distinction, one between human and animal, must be recognized though it does not bear heavily on this conversation. What it 
does establish is an equal playing field of human nature, which, at the same time, remains fluid. For Ferguson, the state of nature is not a temporal location but a state of human interaction with the environment. And because of this he can make a claim that would be detrimental to any of the previous stadial histories we’ve addressed:

"[i]n the condition of the savage, as well as in that of the citizen, are many proofs of human invention; and in either is not any permanent station, but a mere stage through which this traveling being is destined to pass. If the palace be unnatural, the cottage is so no less; and the highest refinements of political and moral apprehension, are not more artificial in their kind, than the first operations of sentiment and reason.” (14)

In this one sentence, Ferguson has leveled both of the main arguments given above for championing a notion of human rights that are defined by their opposition to the inhuman savage condition: namely, a refinement of moral sympathy which brings about a reverence for the individual as inviolable and relative distance from an originary state of nature.

The word that Ferguson frequently uses in reference to attempts to locate a point of civic nascence is conjecture. He denounces what is commonly termed "conjectural history” on the notion that both the "original character of mankind" and the full capacity that various societies have to progress from that point are entirely unknowable. Thus, any claim to the placement of a particular society at one point along a timeline of human progress would be merely conjecture. We might infer, then, (though Ferguson does not seem to make this leap) that there are no “actual savages,” only societies that appear to have an inferior or superior position compared to another society. 
If this is the case, then, any definition of "human" that takes the "savage" as a point of reference is equally fictional. Since Ferguson does not bifurcate nature, human nature functions merely as the result of human interactions with environment; because he does not privilege any particular spot along the pendulum of human "progress," there is no stage at which "the rights of man” are bestowed and no point at which they can be said to be definitively absent. Thus, for Ferguson there are no "rights" as such because "Liberty is a right which every individual must be ready to vindicate for himself” (251). The jingoistic fervor of his prose notwithstanding, we can infer from this that rights (rather than being granted, and thus denied, by virtue of category and distinction) must be performed. 


\section{Works Cited}

Auckland, William E. Principles of Penal Law. London: Printed for B. White, 1771. Print.

Blackstone, William, Edward Christian, Joseph Chitty, Thomas Lee, John E. Hovenden, and Archer Ryland. Commentaries on the Laws of England: In Four Books, with an Analysis of the Work. Vol. 1. Philadelphia: Lippincott, 2008. Internet resource. <http://oll.libertyfund.org/title/2141>

Dagge, Henry. Considerations on Criminal Law. Vol. 2. London: T. Longman and T. Cadell, 1774. Print.

Ferguson, Adam. An Essay on the History of Civil Society. Ed. Fania Oz-Salzberger. Cambridge Texts in the History of Political Thought. Cambridge: Cambridge U P, 2003. Print.

Hunt, Lynn. “The 18th-Century Body and the Origins of Human Rights.” Diogenes 51.3 (2004): 41-56.Academic Search Complete. EBSCO. Web. 10 Aug. 2010.

McGowen, Randall. "The Body and Punishment in Eighteenth--Century England." Journal of Modern History 59.4 (1987): 651-679. JSTOR. Web. 10 Aug. 2010.

Oz-Salzberger, Fania. Introduction. An Essay on the History of Civil Society. By Adam Ferguson. 2003. Cambridge Texts in the History of Political Thought. Cambridge: Cambridge U P, 2003. vii-Xxv. Print. 